\title{
ANALYSIS OF NITRATE CONCENTRATION, PHOSPHATE AND SILICATE RELATIONSHIP WITH THE ABUNDANCE OF PLANKTONIC DIATOMS IN MERAL WATERS, KARIMUN DISTRICT
}

\author{
Rozalina* $^{1}$, Syahril Nedi ${ }^{2}$ dan Irvina Nurrachmi ${ }^{2}$ \\ ${ }^{1}$ Student of The Faculty of Fisheries and Marine Science University of Riau, Pekanbaru \\ ${ }^{2}$ Lecturer at The Faculty of Fisheries and Marine Science University of Riau, Pekanbaru \\ *linar2917@gmail.com
}

\begin{abstract}
Input of nutrients into the waters from various human activities (residential and industry) has the potential to cause changes in the physical, chemical and biological conditions of the waters. The study aims to determine the relationship of concentrations of nitrate, phosphate and silicate with the abundance of diatoms in the Meral waters. The method used is the survey method, the determination of the location of sampling is done by purposive sampling, data analysis (multiple regression). Based in the results of laboratory analysis nitrate concentrations ranged from $0,033-0,051 \mathrm{mg} / \mathrm{l}$, the phosphate concentration ranged from $0,076-0,086 \mathrm{mg} / \mathrm{l}$, and silicate concentration ranged from $0,043-0,052 \mathrm{mg} / \mathrm{l}$. The abundance of diatoms in Tanjung Tiram waters ranged from 90,3 - 208,3 ind/1. The results of statistical analysis of the relationship of nitrate, phosphate and silicate with the abundance of diatoms are expressed in terms of equation $y=58,460+904,562$ Nitrate 251,562 phosphate $+1573,489$ Silicate. This statement explains the concentration of nitrate, silicate positive (+) to the abundance of diatoms and phosphate related negative (-) to the abundance of diatoms. This condition shows that the nutrient concentration in these waters is relatively high so that it affects the abundance of diatoms.
\end{abstract}

Keywords: Diatom, Nitrate, Phosphate, Silicate, Meral

\section{PENDAHULUAN}

Wilayah pesisir adalah suatu kawasan yang merupakan wilayah peralihan antara laut dan daratan, disamping itu juga secara ekologis perlu dijaga kelestarian fungsifungsinya. Wilayah pesisir mencakup bagian laut yang masih dipengaruhi oleh proses-proses alami yang terjadi di darat seperti sedimentasi dan aliran air tawar maupun yang disebabkan oleh aktivitasaktivitas manusia.

Diatom merupakan fitoplankton yang bersifat uniseluler, namun seringkali ditemukan dalam bentuk koloni, yang termasuk kedalam kelas Bacillariophyceae.

kelompok ini merupakan komponen utama yang paling umum dijumpai di perairan laut, diatom ada yang hidup sebagai diatom pelagik dan ada pula yang hidup sebagai diatom bentik (Nontji, 2008).

Unsur hara seperti nitrat, fosfat dan silikat merupakan faktor penting dalam pertumbuhan diatom, senyawa ini merupakan senyawa nutrisi yang berfungsi merangsang pertumbuhan biomasa fitoplankton seperti diatom. 
Meral merupakan salah satu kecamatan yang berada di Kabupaten Karimun. Wilayah ini telah banyak dimanfaatkan masyarakat sebagai daerah pemukiman, perikanan tangkap dan jalur transportasi laut, di daerah ini sering terjadi aktivitas-aktivitas antrophogenik seperti adanya perkilangan kapal, industri pertambangan pasir dan jalur transportasi laut baik itu kapal barang maupun kapal penumpang.

Terbatasnya informasi yang diperoleh tentang kondisi perairan Meral dengan berbagai aktivitas antropogeniknya. Berdasarkan uraian diatas perlu dilakukan penelitian mengenai Analisis Konsentrasi Nitrat, Fosfat dan Silikat Hubungannya dengan Kelimpahan Diatom Planktonik di Perairan Meral Kabupaten Karimun Provinsi Kepulauan Riau..

Tujuan Penelitian ini adalah untuk mengetahui konsentrasi nitrat, fosfat dan silikat, menganalisis kelimpahan diatom planktonik di sekitar perairan Meral serta menganalisis hubungan konsentrasi nitrat, fosfat dan silikat hubungannya dengan kelimpahan diatom planktonik di perairan Meral.

\section{METODE PENELITIAN}

Penelitian ini telah dilaksanakan pada bulan Agustus 2018 yang bertempat di sekitar perairan Meral, Kabupaten Karimun Provinsi Kepulauan Riau. Analisis sampel diatom dilakukan di Laboratorium Biologi Laut sedangkan analisis nitrat, fosfat dan silikat dilakukan di Laboratorium Kimia Laut, Jurusan Ilmu Kelautan Fakultas Perikanan dan Kelautan Universitas Riau.

Metode yang digunakan dalam penelitian ini adalah metode survey, pengambilan sampel dilakukan pada saat air laut pasang. Penentuan titik lokasi penelitian dengan menggunakan purposive sampling dengan memperhatikan aktivitas yang berada disekitar perairan Meral, Lokasi penelitian dibagi atas empat stasiun dengan jarak stasiun kurang lebih 200 (Gambar 1).
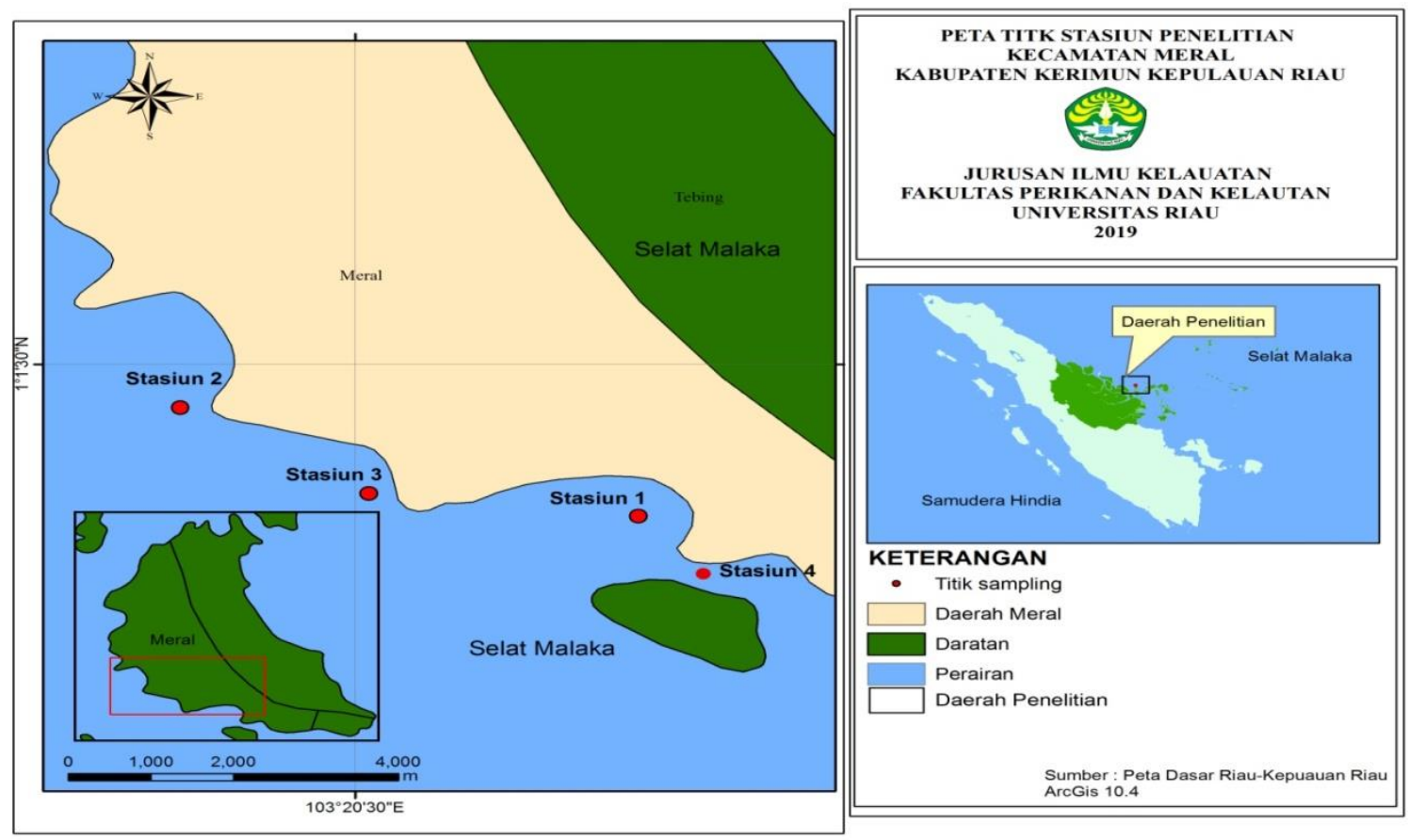

Gambar 1. Peta Lokasi Penelitian 


\section{Penentuan Lokasi Penelitian}

Stasiun I berada di kawasan sekitar pemukiman masyarakat.

Stasiun II berada di kawasan sekitar pelabuhan roro.

Stasiun III terletak di kawasan sekitar PT MOS (Multi Ocean Shipyard). Stasiun IV berada di kawasan sakekitar mangrove.

Pengambilansampelair untuk analisis konsentrasi nitrat, fosfat dan silikat yaitu dengan menggunakan botol sampel. Sampel air diambil dipermukaan sebanyak $100 \mathrm{ml}$ pada saat air laut pasang menggunakan kapal, dan pada sampel nitrat diberi pengawet dengan menambahkan larutan asam sulfat pekat sebanyak 2 tetes. Lalu, botol-botol diberi label dan dimasukkan ke dalam ice box untuk analisis di laboratorium.

Sampel diatom diambil pada saat air laut pasang bersamaan dengan pengambilan sampel nitrat, fosfat dan silikat pada daerah permukaan sebanyak 100 liter menggunakan ember berukuran 10 liter yang sudah di standarisasi terlebih dahulu, kemudian disaring menggunakan plankton net No.25. Hasil penyaringan sebanyak 125 ml dimasukkan ke dalam botol sampel dan diberi pengawet berupa lugol $4 \%$ sebanyak 4 tetes, selanjutnya diberi label dan diamati di laboratorium.

Pengukuran parameter kualitas perairan pada penelitian diukur langsung di lapangan pada saat air laut pasang sebanyak titik sampling, pengambilannya bersamaan dengan pengambilan sampel nitrat, fosfat, silikat dan diatom. Parameter yang diukur yaitu salinitas, suhu, kecepatan arus, kecerahan, oksigen terlarut dan $\mathrm{pH}$.

Pengamatan diatom dilakukan dengan cara meneteskan air sampel ke objek glass dengan metode sapuan dengan perbesaran 10x10 menggunakan mikroskop Olympus CX21. Selanjutnya jenis diatom yang terlihat diidentifikasi berpedoman pada buku Yamiaji (1976) dan Davis (1995). Kelimpahan diatom dihitung dengan merujuk pada rumus Fachrul (2007) dengan rumus:

$$
\mathrm{N}=\mathrm{n} \times \mathrm{Vr} / \mathrm{Vo} \times 1 / \mathrm{Vs}
$$

Dimana :

$\mathrm{N}=$ Jumlah ind per liter

$\mathrm{n}=$ Jumlah ind per liter

$\mathrm{Vr}=$ Volume air tersaring $(125 \mathrm{ml})$

$\mathrm{Vo}=$ Volume air yang diamati $(0,06 \mathrm{ml})$

Vs = Volume air yang disaring $(100 \mathrm{ml})$

Analisis nitrat dilakukan dengan menggunakan metode Brucine. Pengukuran nitrat dilakukan dengan cara menyaring air sampel sebanyak $15 \mathrm{ml}$ dengan menggunakan whatman paper No. 42 dan vaccum pump sebagai alat penghisap, kemudian ditambahkan larutan EDTA sebanyak 4 tetes lalu disaring dengan menggunakan colom $\mathrm{Cd}$, kemudian ditambahkan dengan larutan naptil 10 tetes dan larutan sulfanilamide 10 tetes, dilihat perubahan warna dari bening menjadi warna merah muda, dikocok dan diukur dengan menggunakan spectrophotometer dengan panjang gelombang $543 \mathrm{~nm}$.

Analisis fosfat dilakukan dengan cara menyaring air sampel sebanyak $15 \mathrm{ml}$ dengan menggunakan whatman paper No. 42 dan vaccum pump sebagai alat penghisap, kemudian ditambahkan larutan amonium molibdat sebanyak 10 tetes dan ditambahkan dengan $\mathrm{SnCl} 2$ sebanyak 3 tetes, dilihat perubahan warna dari bening menjadi warna biru dan diukur dengan menggunakan spectrophotometer dengan panjang gelombang $490 \mathrm{~nm}$.

Analisis silikat dilakukan dengan cara menyaring air sampel sebanyak $15 \mathrm{ml}$ dengan menggunakan whatman paper No. 42 dan vaccum pump sebagai alat penghisap, kemudian ditambah larutan $\mathrm{HCl}$ sebanyak 5 tetes dan ditambah larutan ammonium molibdate sebanyak 10 tetes, diamkan selama 10 menit kemudian ditambah 10 tetes asam oksalat dan diamkan selama 10 menit lihat perubahan dari warna bening menjadi kuning dan 
diukur dengan menggunakan spectrophotometer pada panjang gelombang $410 \mathrm{~nm}$.

Analisis sidik ragam atau anova digunakan untuk mengetahui apakah terdapat perbedaan distribusi disetiap stasiun. Jika hasil analisis sidik ragam memperlihatkan perbedaan yang nyata, maka dilanjutkan dengan uji LSD untuk mengetahui perbedaan tersebut.

Analisis berganda digunakan untuk mengetahui ada atau tidaknya hubungan konsentrasi nitrat, fosfat dan silikat dengan kelimpahan diatom. Menurut Hidayat et al. (2013), analisis regresi berganda ini digunakan untuk memprediksi hubungan variable bebas terhadap variabel terikat dengan tujuan untuk melihat ada atau tidaknya hubungan diantara ketiga variabel tersebut. Kemudian bagaimana arah hubungannya dan seberapa kuatkah hubungan tersebut, berikut persamaan regresinya :

$$
y=a+b x 1+b x 2+b x 3
$$

Dimana :

$$
\begin{array}{ll}
\mathrm{y} & =\text { Kelimpahan diatom (ind/l) } \\
\mathrm{a} & =\text { konstanta } \\
\mathrm{b} & =\text { koefisiensi } \\
\mathrm{x} 1 & =\text { konsentrasi Nitrat }(\mathrm{mg} / \mathrm{l}) \\
\mathrm{x} 2 & =\text { konsentrasi Fosfat }(\mathrm{mg} / \mathrm{l}) \\
\mathrm{x} 3 & =\text { konsentrasi Silikat }(\mathrm{mg} / \mathrm{l})
\end{array}
$$

\section{HASIL DAN PEMBAHASAN} Kondisi Umum Lokasi Penelitian

Meral merupakan salah satu kecamatan yang berada di Kabupaten Karimun Provinsi Kepulauan Riau. Secara astronomis Kecamatan Meral terletak diantara $00^{\circ} 57^{\prime} 25^{\prime \prime}$ sampai dengan $1^{\circ} 09^{\prime} 2$ " Lintang Utara dan $103^{\circ} 0^{\prime} 17^{\prime} 5^{\prime \prime}$ sampai dengan $103^{\circ} 0^{\prime} 32^{\prime} 38^{\prime \prime}$ Bujur Timur, luas wilayah Kecamatan Meral $\pm 76 \mathrm{~km} 2$. Secara geografis Kecamatan Meral berbatasan langsung dengan Sebelah Utara Berbatasan dengan Selat Malaka, Sebelah Barat Berbatasan dengan Meral Barat Sebelah Selatan Kabupaten Bengkalis dan Pelalawan, Sebelah Timur berbatasan dengan Kecamatan Tebing. Kecamatan Meral mempunya enam kelurahan diantaranya yaitu Kelurahan Baran Timur, Kelurahan Baran Barat, Kelurahan Meral kota, Kelurahan Sungai Pasir, Kelurahan Sungai Raya dan Kelurahan Parit Benut.

Kecamatan Meral merupakan kawasan strategis dan potensial sebagai wilayah pengembangan perekonomian dan industri serta investasi galangan kapal. Sebagian dari luas wilayah Kecamatan Meral umumnya terdiri dari daratan $80 \%$, tanah berbukit sebesar $20 \%$ dengan ketinggian ratar-rata 3 meter di atas permukaan laut. Selain itu juga Kecamatan Meral masih terdapat pulau-pulau yang tidak berpenghuni diantaranya yaitu Pulau Merak, Pulau Babi, Pulau Hantu Kecil, Pulau Betek, Pulau Tambelas, Pulau Sekajang Pulau Luko Peti dan Pulau Besurut (Kantor Camat Meral, 2012).

Parameter Kualitas Perairan

Hasil pengukuran parameter kualitas perairan pada setiap stasiun penelitian dapat dilihat pada Tabel 1 .

Tabel 1. Parameter Kualitas Perairan

\begin{tabular}{lccccc}
\hline \multicolumn{1}{c}{ Parameter Kualitas Perairan } & Satuan & \multicolumn{4}{c}{ Stasiun } \\
\cline { 3 - 6 } & & I & II & III & IV \\
\hline $\mathrm{pH}$ & & 7 & 5 & 6 & 6 \\
Suhu & ${ }^{0} \mathrm{C}$ & 30 & 32 & 31 & 31 \\
Salinitas & $\mathrm{ppt}$ & 32 & 28 & 31 & 30 \\
Oksigen Terlarut & $\mathrm{mg} / 1$ & 8,15 & 5,20 & 6,20 & 6,20 \\
Kecerahan & $\mathrm{cm}$ & 120 & 65 & 90 & 85 \\
Kecepatan Arus & $\mathrm{m} / \mathrm{det}$ & 0,18 & 0,13 & 0,16 & 0,16 \\
\hline
\end{tabular}


Dari Tabel 1 diketahui bahwa $\mathrm{pH}$ di perairan meral berkisar antara 5-7, suhu berkisar antara antara 30-32 0C, salinitas berkisar antara 28-32 ppt, oksigen terlarut berkisar 5,20-8,15 mg/l, kecerahan $65-120$ $\mathrm{cm}$ dan kecepatan arus berkisar 0,13-0,18 $\mathrm{m} / \mathrm{det}$.

\section{Konsentrasi Nitrat, Fosfat dan Silikat di Perairan Meral}

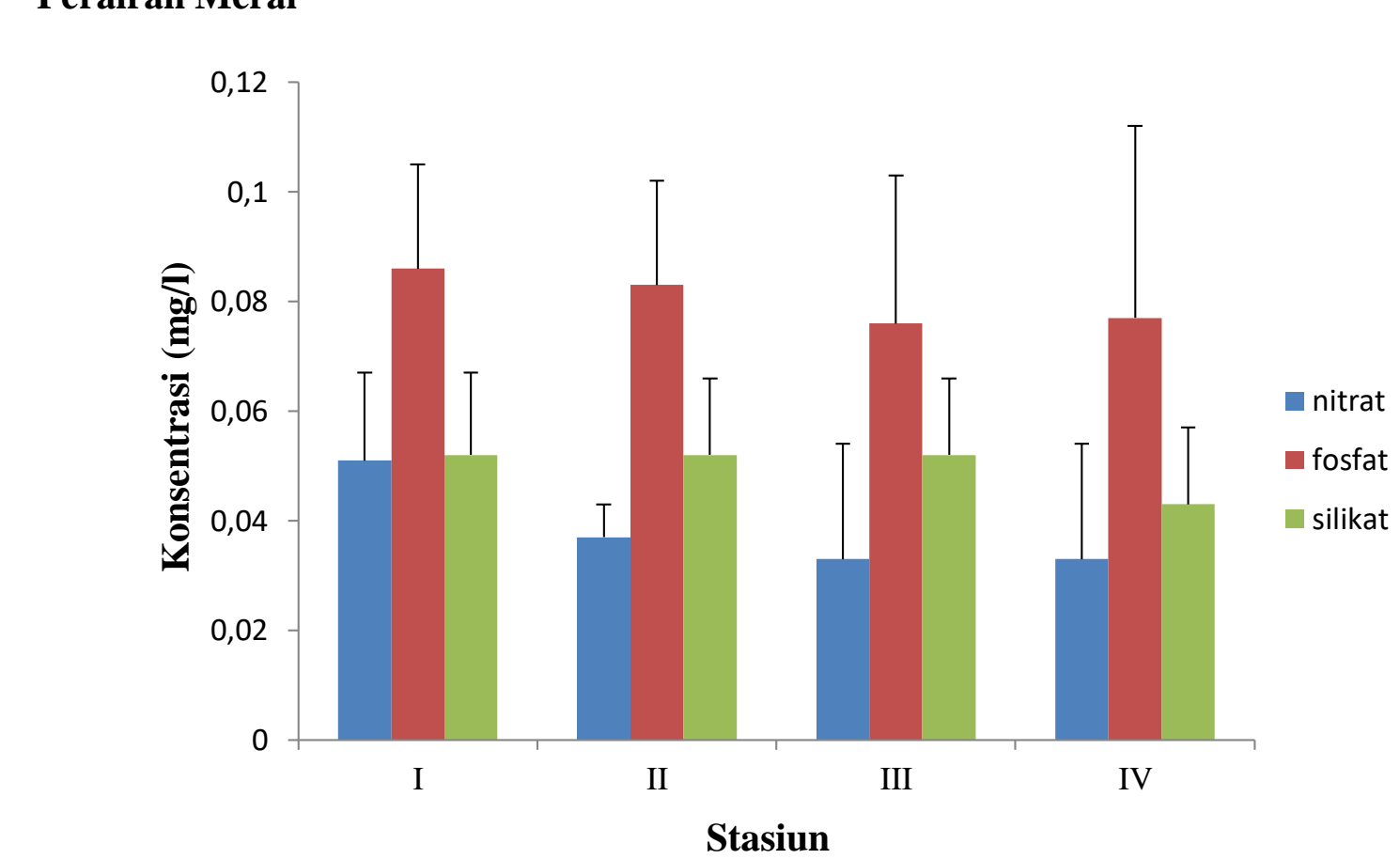

Gambar 2. Rata-rata Konsentrasi Nitrat, Fosfat dan Silikat
Zat hara merupakan zat-zat yang diperlukan dan mempunyai pengaruh proses dan perkembangan hidup organisme seperti fitoplankton, unsur hara yang diukur pada penelitian ini adalah nitrat, fosfat dan silikat, untuk melihat nilai konsentrasi nitrat, fosfat dan silikat antar stasiun dapat dilihat pada Gambar2.
Berdasarkan Gambar 2 diketahui bahwa konsentrasi nitrat yang paling tinggi pada stasiun I dengan rata-rata $0,051 \mathrm{mg} / \mathrm{l}$, tingginya konsentrasi nitrat di stasiun ini dibandingkan dengan stasiun lainnya dikarenakan stasiun ini berada di daerah pemukiman masyaraka, aktivitas didaerah ini terdiri dari buangan limbah rumah tangga serta aktivitas yang berada didaratan. Amin (2017) menyatakan bahwa kadar nitrat di perairan dekat pantai cenderung tinggi akibat adanya tambahan dari daratan melalui sungai-sungai. Sebagaimana pernyataan Saribu et al. (2017) menambahkan bahwa perbedaan kandungan nitrat dari pemukiman hingga laut lepas pantai mengalami penurunan disebabkan karena perbedaan kuantitas buangan limbah di lingkungan masingmasing stasiun, sedangkan konsentrasi nitrat terendah terdapat pada stasiun III dan IV dengan rata-rata $0,033 \mathrm{mg} / \mathrm{l}$, rendahnya konsentrasi nitrat di stasiun ini diduga karena stasiun ini berada jauh dari aktivitas masyarakat. Muchtar et al. (2012), dikatakan bahwa kadar nitrat yang rendah dipermukaan karena zat hra tersebut telah dimanfaatkan diatom untuk pertumbuhan hidup.

Konsentrasi fosfat tertinggi terdapat pada stasiun I dengan nilai $0,086 \mathrm{mg} / \mathrm{l}$, tingginya konsentrasi fosfat diduga karena 
mendapatkan aliran unsur hara dari daratan atau endapan dari daratan saat terjadi hujan, dan juga dari hasil kegiatan antropogenik lainnya. Hal ini sesuai dengan pernyataan Patty et al. (2015) menyatakan bahwa konsentrasi fosfat yang tinggi disebabkan oleh difusi fosfat dari sedimen, ditambah lagi dengan pernyataan Handoko et al. (2013) proses pengadukan pada dasar perairan dan proses sirkulasi dari permukaan akan sangat mempengaruhi besarnya konsentrasifosfat, sedangkan konsentrasi terendah terdapat pada stasiun III dengan nilai $0,076 \mathrm{mg} / \mathrm{l}$, rendahnya konsentrasi fosfat pada stasiun ini karena daerah tersebut jauh dari daratan, selain itu kemungkinan diduga telah dimanfaatkan diatom. Muchtar (2012) rendahnya konsentrasi fosfat dipermukaan kemungkinan dapat disebabkan oleh aktivitas fitoplankton yang intensif.

Konsentrasi silikat tertinggi terdapat pada stasiun I, II dan III dengan nilai 0,052 $\mathrm{mg} / \mathrm{l}$, Tingginya konsentrasi silikat dikarenakan aktivitas alami dari perairan itu sendiri dan aktivitas dari masyarakat. Menurut Simanjuntak (2012), sumber utama kandungan silikat dalam suatu perairan banyak dipengaruhi proses erosi serta curah hujan. Nutrien silikat diperlukan dan berpengaruh terhadap proses pertumbuhan dan perkembangan diatom untuk pembentukan kerangka dinding selnya, sedangkan konsentrasi silikat terendah terdapat pada stasiun IV dengan nilai $0,043 \mathrm{mg} / \mathrm{l}$, rendahnya konsentrasi silikat pada stasiun ini diduga karena stasiun ini tidak terdapat pengaruh sungai dan adanya pengaruh pasang surut dapat mempengaruhi rendahnya nilai konsentrasi silikat disuatu perairan. Manasrah et al.(2006) juga mengatakan fenomena arus laut juga berperan dalam penyebaran konsentrasi silikat.

\section{Jenis dan Kelimpahan Diatom}

Jenis diatom yang ditemukan di perairan Meral dapat dilihat pada Tabel 2.

Tabel 2. Spesies Diatom Pada Setiap Stasiun

\begin{tabular}{llcccc}
\hline No & Spesies & \multicolumn{5}{c}{ Stasiun } \\
\cline { 2 - 6 } & & I & II & III & IV \\
\hline 1 & Nitzschia sp & + & + & - & + \\
2 & Pleurosigma sp & + & - & - & + \\
3 & Navicula sp & + & - & + & - \\
4 & Isthmia sp & + & + & + & + \\
5 & Coscinodiscus sp & + & + & - & - \\
6 & Thalassiosira sp & + & - & - & - \\
7 & Odontella sp & + & + & + & + \\
8 & Leptocylindrus sp & - & + & - & + \\
9 & Bacillaria sp & 8 & 5 & - & - \\
\hline & Jumlah & & & 3 & 4 \\
\hline
\end{tabular}

Pada Tabel 2 dapat dilihat spesies diatom yang paling banyak ditemukan terdapat pada stasiun I dengan jumlah 8 spesies, dan paling sedikit ditemukan di stasiun 3 dengan jumlah 3 spesies.
Kelimpahan diatom pada perairan Meral memiliki nilai bervariasi tetapi tidak begitu jauh dan dapat dilihat pada Tabel 3 . 
Tabel 3.Kelimpahan Diatom Pada Setiap Stasiun Penelitian

\begin{tabular}{cc}
\hline Stasiun & Kelimpahan diatom (ind/l) \pm Stdev \\
\hline I & $208,3 \pm 36,8$ \\
II & $90,3 \pm 43,35$ \\
III & $152,8 \pm 12,07$ \\
IV & $152,8 \pm 43,35$ \\
\hline
\end{tabular}

Berdasarkan Tabel 3 terlihat bahwa ratarata kelimpahan diatom pada masingmasing stasiun bervariasi. Nilai rata-rata kelimpahan diatom yang ditemukan setiap stasiun di perairan Meral berkisar antara 90,3-208,3 ind/1 dengan rata-rata kelimpahan tertinggi ditemukan di stasiun I yaitu 208,3 ind/l, tingginya kelimpahan diatom pada stasiun I dari pada stasiun lainnya karena adanya aktivitas pemukiman masyarakat yang menghasilkan kegiatan rumah tangga seperti sisa-sisa makanan dan beberapa organisme yang mati yang dibuang keperairan dan sebagainya. Yuan et al. (2012), menyatakan bahwa adanya limbah dari aktivitas manusia dapat menyebabkan peningkatan diatom, selain itu tingkat kecerahan perairan pada stasiun ini cukup tinggi yaitu $120 \mathrm{~cm}$ sehingga cahaya matahari yang menembus kekolom perairan dapat dimanfaatkan diatom untuk fotosintesis. Hal ini juga diperkuat oleh pendapat Hidayat (2013) kecerahan berperan penting karena erat hubungannya dengan proses fotosintesis yang terjadi diperairan. Sedangkan kelimpahan diatom terendah terdapat pada stasiun II dengan rata-rata kelimpahan 90,3 ind/l, rendahnya kelimpahan diatom pada stasiun ini diduga berkaitan erat dengan kondisi perairan dan $\mathrm{pH}$ yang rendah yaitu 5. Stasiun II yang berada disekitar pelabuhan. Asriyana dan Yuliana (2012) juga menyatakan $\mathrm{pH}$ yang ideal untuk kehidupan diatom diperairan adalah 6-8,5

Konsentrasi Nitrat, Fosfat dan Silikat Hubungannya Dengan Kelimpahan Diatom di Perairan Meral
Berdasarkan hasil analisis regresi berganda didapat nilai kefisien korelasi (R) dengan nilai 0,432 menunjukkan bahwa hubungan antara konsentrasi nitrat, fosfat dan silikat pada diatom adalah sedang. Kemudian nilai $\mathrm{R}$ square (R2) bernilai 0,187 artinya persentasi sumbangan dari variabel nitrat, fosfat dan silikat terhadap diatom adalah $18,7 \%$ dan sisanya $81,3 \%$ dipengaruhi oleh faktor lain. Selanjutnya diperoleh persamaan regresi berganda sebagai berikut:

$\mathrm{y}=58,460+904,562-251,360+$ 1537,489

Hasil dari regresi berganda tersebut memperlihatkan bahwa zat hara yang memiliki hubungan searah (berbanding lurus) adalah nitrat dan silikat. Sedangkan zat hara yang memiliki hubungan berbanding terbalik yaitu fosfat.

Hubungan konsentrasi nitrat dengan kelimpahan diatom memiliki nilai positf, dengan nilai koefisien $=+904,562$ dengan nilai koefisien determinasi $(\mathrm{R} 2)=0,187$ dan koefisien korelasi $\mathrm{r}=0,432$. Konsentrasi nitrat dengan kelimpahan diatom mempunyai hubungan yang sedang dengan nilai yang positif, dimana semakin tinggi konsentrasi nitrat maka kelimpahan diatom juga meningkat. Hal ini sesuai dengan pernyataan Permatasari et al. (2016) nitrat merupakanzat hara utama yang dibutuhkan oleh diatom untuk tumbuh dan berkembang dengan baik, besarnya konsentrasi nitrat diperairan akan merangsang pertumbuhan diatom.

Hubungan konsentrasi fosfat dengan kelimpahan diatom memiliki nilai 
negatif dengan nilai koefisien $=-251,360$ dengan nilai koefisien determinasi $(\mathrm{R} 2)=$ 0,187 dan koefisien korelasi $\mathrm{r}=0,544$. Konsentrasi fosfat dengan kelimpahan diatom mempunyai hubungan yang sedang dengan nilai negatif dimana dengan meningkatnya konsentrasi fosfat maka kelimpahan diatom akan menurun. Hal ini sesuai dengan pernyataan Hasrun et al. (2013) bahwa tingginya konsentrasi fosfat disebabkan oleh pemanfaatan diatom kurang optimal, ditambah lagi dengan pernyataan Garno et al.(2016) mengatakan bahwa fosfat adalah unsur hara yang sering menjadi factor pembatas pertumbuhan diatom di perairan.

Hubungan konsentrasi silikat memiliki nilai positif dengan nilai koefisien $=$ $+1573,489$ dengan nilai koefisien determinasi $(\mathrm{R} 2)=0,187$ dan koefisien korelasi $\mathrm{r}=0,432$. Hubungan konsentrasi silikat dengan kelimpahan diatom mempunyai hubungan yang sedang, dimana kenaikan konsentrasi silikat akan diikuti dengan kelimpahan diatom. Hal ini sesuai dengan pernyataan Lukman et al. (2014) yaitu silikat terlarut di perairan pesisir dan laut berperan penting dalam pertumbuhan fitoplankton seperti diatom, ditambah lagi dengan pernyataan Risamasu dan Prayitno (2011) yaitu silikat dibutuhkan untuk pembentukan dinding sel pada diatom dan tergantung pada tersedianya silikat yang terlarut di perairan tersebut.

\section{KESIMPULAN DAN SARAN Kesimpulan}

Konsentrasi nitrat berkisar0,033$0,051 \mathrm{mg} / \mathrm{l}$, fosfat $0,076-0,086 \mathrm{mg} / \mathrm{l} \mathrm{dan}$ silikat 0,043-0,052 mg/l. Kandungan nutrien di perairan Meral termasuk dalam kategori perairan oligotrofik (kurang subur). Kelimpahan diatom planktonik di perairan Meral berkisar 90,3-208,3 ind/1, kelimpahan diatom tertinggi terdapat di stasiun I dan terendah di stasiun II. Hasil dari regresi berganda hubungan konsentrasi nitrat, fosfat dan silikat dengan kelimpahan diatom planktonik termasuk kriteria sedang. Unsur hara berpengaruh 18,7\% dan 81,3\% di pengaruhi oleh kualitas air.

Perlu dilakukan penelitian lanjutan mengenai konsentrasi nitrat, fosfat dan silikat dengan kelimpahan diatom planktonik dengan memperbanyak jumlah stasiun, disarankan juga agar pemerintah dan masyarakat setempat untuk tetap menjaga lingkungan perairan tersebut.

\section{DAFTAR PUSTAKA}

1. Amin. M., S. Nedi, dan I. Nurrachmi. (2017). Analisis Tingkat Kesuburan Perairan Muara Sungai Mesjid Kota Dumai Ditinjau Dari Nitrat, Fosfat dan Kelimpahan Diatom. Jurnal Online Mahasiswa. Universitas Riau. Pekanbaru.

2. Asriyana dan Yuliana. (2012). Produktivitas Perairan (P. 278). Bumi Aksara. Jakarta.

3. Davis, C. C. (1995). The Marine and Fresh Water Plankton. USA : Michigan State Uiversity Press.

4. Fachrul, M. F. (2007). Metode Sampling Bioekologi (P. 198). Bumi Aksara, Jakarta.

5. Garno, Y. S. Dan W. Komarawidjaja. (2016). Status Kualitas Perairan Pesisir Barat .Jurnal Teknik Lingkungan. Volume 17(1).

6. Hasrun, L., K. Ma'ruf dan Salwiyah. (2013).Studi Biodiversitas Diatom Bentik pada Areal Mangrove di Perairan Kecamatan Kolono Kabupaten Konawe Selatan. Jurnal Mina Laut Indonesia. Volume 2(6) Pages 35-47.

7. Hidayat, R., L. Viruly dan D. Azizah. (2013). Kajian Kandungan Klorofil-a pada Fitoplankton Terhadap Parameter Kualitas Air di Teluk Tanjung Pinang Kepulauan Riau. Universitas Maritim Raja Ali Haji. KEPRI. 
8. Handoko.,Yusuf. M., Wulandari, S, Y. (2013). Sebaran Nitrat dan Fosfat Dalam Kaitannya Dengan Kelimpahan Fitoplankton di Kepulauan Karimunjawa Jurnal Oseanografi. Volume 2(3).

9. Kantor Camat Meral (2012). Profil Kecamatan Meral Kabupaten Karimun.

10. Lukman, M., A. Nasir, K. Amri, R, Tambaru, M. Hatta, Nurfadilla, dan R. J. Noer. (2014). Silikat Terlarut di Perairan Pesisir Sulawesi Selatan. Jurnal Ilmu dan Teknologi Kelautan. Volume 6(2) Pages 461-478.

11. Manasrah, R., Raheed, M \& Badran, M.I. (2006). Relationship Between Water Temperature, Nutrient and Dissolved Oxygen in The Northern. Oceanologia. Volume 48 (2).

12. Muchtar dan Muswerry. (2012). Distribusi Zat Hara Fosfat, Nitrat Dan Silikat Di Perairan Kepulauan Natuna. Jurnal Ilmu dan Teknologi Kelautan Tropis. Volume 4 (2).

13. Nontji, A. (2008). Plankton Laut (P. 331). LIPI Press. Jakarta.

14. Padang, A. (2012). Peran Diatom Bagi Produktivitas Primer di Lingkungan Bentik. Jurnal Bimafika. Volume (4) Pages 420-424.

15. Patty, I. S. (2015). Kadar Nitrat dan Oksigen Terlarut di Perairan Pulau Talise Sulawesi Utara. Jurnal Ilmia Platax. Volume 1(4) Pages 167-176.

16. Permatasari, R, D., Djuwito dan Irwani. (2016). Pengaruh Kandungan Nitrat dan Fosfat Terhadap Kelimpahan Diatom di Muara Sungai Wulan. Journal of Maquares. Volume 5(4) Pages 224-232.

17. Risamasu, J. F dan H. B. Prayitno. (2011). Kajian Zat Hara Fosfat, Nitrit, Nitrat dan Silikat di Perairan Kepulauan Matasiri, Jurnal Kalimantan Selatan. Volume 16(3) Pages 135-142.

18. Saribu, M. D., A. Mulyadi, dan I. Nurrachmi. (2017). Studi Kelimpahan Diatom (Baccilariophyta) Planktonik Dengan Konsentrasi Nitrat dan Fosfat di Perairan Belawan Provinsi Sumatera Utara. Jurnal Online Mahasiswa. Universitas Riau. Pekanbaru.

19. Simanjuntak, (2012). Kualitas Air Laut Ditinjau Dari Aspek Zat Hara, Oksigen Terlarut Dan pH Di Perairan Banggai, Sulawesi Tengah. Jurnal Ilmu dan Teknologi Kelautan Tropis. Volume 4 (2).

20. Yamaji, I. 1976. Illustration of the Marine Plankton of Japan 8th (P.563) Hoikhusa Publissing Co. Ltd. Tokyo.

21. Yuan, X.,P.M. Gilbert, J.Xu, H. Liu, M. Chen, K. Yin danP.J. Horrison. (2012). In Organic Nitrogen Uptake By Phytoplankton and Bacteria in Hongkong Waters. Estuaries and Coasts. Volume 35(1) Pages 325-334. 